\title{
Exit proficiency: The proof of the pudding
}

\section{Jonathan Upjohn}

\section{(2) OpenEdition \\ Journals}

Electronic version

URL: http://journals.openedition.org/asp/2578

DOI: $10.4000 /$ asp. 2578

ISBN: 978-2-8218-0380-0

ISSN: 2108-6354

\section{Publisher}

Groupe d'étude et de recherche en anglais de spécialité

\section{Printed version}

Date of publication: 1 December 1999

Number of pages: 305-322

ISSN: 1246-8185

\section{Electronic reference}

Jonathan Upjohn, « Exit proficiency: The proof of the pudding », ASp [Online], 23-26 | 1999, Online since 09 November 2011, connection on 19 April 2019. URL : http://journals.openedition.org/asp/2578 ;

DOI : $10.4000 /$ asp. 2578

This text was automatically generated on 19 April 2019

Tous droits réservés 


\title{
Exit proficiency: The proof of the pudding
}

\author{
Jonathan Upjohn
}

\section{Introduction}

1 It is doubtless legitimate to assume, that slowly but surely, year by year, the essence of what we, as teachers and researchers consider to be the key areas of interest and importance to our profession are distilled in the pages of the "Sommaires" of ASp, a sort of tribal history as it were. And, indeed, a cursory examination reveals, as might be expected, a portrait of ourselves, in the shape of a wide profusion of articles on different aspects of language, of pedagogy and of methodology. There have been papers on linguistic aptitude, on pedagogical aims and on needs analysis: different approaches to facilitating language learning have been debated, cognitive issues and the challenges of the new technologies have been discussed.

2 This paper, however, will look at what seems to be a sorely (and surprisingly) neglected area, namely the evaluation of students' exit proficiency. Arguably, this is one of the most important functions of our profession. For, to misuse a saying, "there is many a slip between the theory and the practice" and it is only by identifying what has in fact been mastered and (more threateningly but more interestingly) what we have failed to accomplish, that empirical data can be assembled to fine tune the hunches, theories and convictions on which we build our programmes. The attempts to validate our practice provide essential data, both pedagogically crucial for informing future course design, and strategically necessary for decisions to be made as to whether the teaching of a course should be continued, reinforced or discontinued.

3 In the present study, an analysis is made of the lexical knowledge, of 48 DESS students, specialising in signal processing. Although this survey covers only lexical competence, it is argued that the results have far reaching implications for University ESP courses in terms of professional and functional skills. 


\section{Premise 1} is professional. That is to say, the language is taught within the framework of ESP in order to provide a potential work tool both during the students' studies and subsequently, as a work qualification in the professional world.

\section{Premise 2}

6 The "non-negotiable" minimum competence to be attained for such a work tool is autonomous reading comprehension ${ }^{1}$ within the given.

\section{Premise 3}

7 The third premise is that a mastery of a core lexis is of cardinal importance for reading comprehension. Over recent years, it has been more and more widely acknowledged that lexical mastery is the single most important factor in reading comprehension, cf. Laufer (1997), Coady (1997), Ulijn \& Salager-Meyer (1998). As Laufer quoting Alderson (1984) says:

some sort of threshold or competence ceiling (in the lexis) has to be attained before existing abilities in the first language can begin to transfer. (1997: 21)

\section{Defining a core lexis}

8 There have been several separate but largely parallel proposals as to the lexical prerequisites for the purposes of professional and academic study: approximately 5,000 lexical items. (Estimated coverage 90-95\%)

10 Nation \& Newton (1997), who analyse the lexis specifically in relation to coverage of academic texts, have largely similar results (see Fig. 1).

Figure 1. Nation \& Newton (1997) - Core Vocabulary

\begin{tabular}{|l|l|l|}
\hline & Number of words & Text coverage \% \\
\hline $\begin{array}{l}\text { High frequency words } \\
(2,000 \text { headwords) }\end{array}$ & 3,200 & $87 \%$ \\
\hline $\begin{array}{l}\text { Academic vocabulary } \\
\text { (800 headwords) }\end{array}$ & 1,280 & $8 \%$ \\
\hline Total & 4,500 & $95 \%$ \\
\hline (Low frequency words $\left.{ }^{3}\right)$ & 123,200 & $2 \%$ \\
\hline
\end{tabular}

11 The Lexis of Minimum Competence in Scientific English (MCSE) (Upjohn, Blattes and Jans, 1987), although starting from different premises arrives at virtually the same conclusions. MCSE relies heavily on French cognates which, for historical and geo-political reasons, constitute such a preponderant part of the intellectual heritage and the academic and 
scientific registers of the English language. For francophones, such words are largely transparent, thus, the aim was to tailor-make (? if one may say such a thing) a core for the specific needs of French students embarking on scientifically oriented courses at the University.

Figure 2. Lexis: Minimum Competence in Scientific English (Upjohn et al. 1991)

\begin{tabular}{|l|l|l|}
\hline & $\begin{array}{c}\text { Number of } \\
\text { words }\end{array}$ & $\begin{array}{c}\text { Coverage (scientific } \\
\text { text) }\end{array}$ \\
\hline $\begin{array}{l}\text { Assumed School Vocabulary (1,200 most frequent } \\
\text { words Cambridge lexicon) }\end{array}$ & $\mathbf{1 , 2 0 0}$ & \\
\hline French cognates & 2,600 approx. & \\
\hline MCSE Lexis (600 headwords) & $\mathbf{9 6 0}$ & \\
\hline Total & $\mathbf{4 , 7 4 0}$ & $\mathbf{9 3 \%}$ \\
\hline
\end{tabular}

\section{Method}

12 The study involved 48 DESS students, ${ }^{4}$ studyingsignal processing and following a newlyinitiated, 1-semester, 24-hour course in English. The catchment area for recruitment was national. Three groups were formed using the MCQ section of the Oxford Placement Test. As could be expected, the overall proficiencies of the students ${ }^{5}$ varied considerably, ranging from students who had obtained 166 / 200 in the OPT, described as "Advanced proficient users"to students obtaining no more than 97 / 200, described as "Basic, very limited users". All of the students had previously studied English at University, the duration varying from 25 hours (8 students) to 200 hours ( 7 students - mainly students from Maths Sup./Spé.), with an average of nearly 87 hours perstudent. Three of the students had had significant experience of living abroad, 2 having studied at Englishspeaking Universities (respectively 4 and 9 months) and another who, over a period of 4 years, had had regular experience of immersion in the US, totalling 3 months in all.

13 Although the primary objective of the course was to reactivate and strengthen reading skills, a considerable amount of practice was done in oral work in general, and OHP presentation skills in particular. This was done for pedagogical reasons: to provide an output for the reading tasks, but also because OHP skills were considered "per se" as a relevant ESP component for these students. Both linguistic and procedural aspects were taken into account. Two factors were very much to the fore during course design:

- An assumed language level corresponding to what might reasonably be expected of 5 th year university students, that is to say students who (in most cases) had studied English for 650 hours in the secondary system, followed by another 80 hours as part of the scientific curriculum.

- The potential real-world demands of industry: i.e. being able to use subject-related documents (research, instructional and technology) and, to a lesser extent, to be able to give oral accounts of work or articles in one's own field. 
14 That was the theory. It was soon found, however, that the aims of lessons were rarely attained as progress was continually frustrated and work retarded by serious low level linguistic problems of lexical comprehension. In order to clarify the situation a diagnostic test of lexical knowledge was undertaken.

\section{Diagnostic test}

15 The test took place in week 4. In order to have some sort of benchmark for comparative purposes it was decided to reuse a test that had been originally used in 1987 during the preparation stages of Minimum Competence in Scientific English, (Upjohn 1991). The test consisted of the following items (see fig. 3).

Figure 3. Lexis Test: DEUG Entry -1987

\begin{tabular}{|l|l|l|}
\hline A & B & C \\
\hline Busy & Manage & Alloy \\
\hline Grow & Wave & Magnet \\
\hline Need & Afford & Reading \\
\hline Below & Either & Update \\
\hline Wrong & Likely & Framework \\
\hline Rise & Believe & Hardware \\
\hline Deep & Share & Monitor \\
\hline Between & Among & Cross-section \\
\hline Bottom & Agree & Shift \\
\hline Low & Suitable & Reliable \\
\hline
\end{tabular}

16 The words in bold have not been retained in the discussion below (Fig. 4) as, for various reasons, they have little discriminatory value. ${ }^{6}$

As can be seen, the test was designed to cover 3 sections:

A - primary level (Cambridge English Lexicon, levels 1-2) (Hindmarsh, 1980),

B - intermediate level (Cambridge English lexicon, levels 3 - 4),

C - semi technical vocabulary belonging to a scientific register.

These 3 areas broadly correspond to a cross-section of what can be considered as the core language for scientific studies.

18 After the test had been marked and returned, the students were informed that a second test would be carried out at the end of the course (Week 13) as part of the final evaluation. The contents of the second test were based on the lexis defined in MCSE. The 
students were informed that it would include only those items that had been encountered and highlighted in texts used during the course. This test was introduced for purposes both of pedagogy and evaluation; more explicitly:

- one aim was to send a clear message of learning priorities to the students.

- the other aim was to obtain better factual data on lexical knowledge of DESS students at the end of their university language learning experience.

The lexical items were tested in isolation; the students being required to provide either a translation or a synonym for a single word. Deviant translations, provided they indicated an understanding of the word root, were accepted as correct. Testing without context was deemed, in the present circumstances, to be the most appropriate (cf. Nurweni and Read 1999) as what was required was unequivocal information concerning the state of lexical knowledge - that is to say, immediate access to meaning ("sight knowledge" Laufer 1997: 22). It was important to avoid interference from ancillary competencies such as top-down knowledge, schemata, guessing, or other.

\section{Results}

The table (Fig. 4) below gives results for the four different categories of students in $\%$ of correct answers:



This 4th group consisted of 3 students who had already followed a syllabus specifically designed to provide a core lexis for French students in a scientific university. (The DEUG Minimum Competence in Scientific English course at the Université Joseph Fourier in 1995.) It should be noted that there were only 3 students in the IMMERSION and the LEX-SYLL groups. ${ }^{7}$ The results of the former are not included in the DESS total on the grounds that their lexical competence could not be primarily attributed to University teaching. Likewise, the results of the 3 LEX-SYLL students are listed separately. The vocabulary items are listed according to their categories (see Fig. 3.).

Figure 4. Lexis Test (DEUG 1987 - DESS Week 4 1998)

\begin{tabular}{|l|l|l|l|l|l|l|}
\hline & $\mathbf{1}$ & $\mathbf{2}$ & $\mathbf{3}$ & $\mathbf{4}$ \\
\hline TEST ITEMS & $\begin{array}{l}\text { DEUG1987 } \\
\text { (entry test) }\end{array}$ & DESS 1998 & DESS 1998 IMMERSION & $\begin{array}{l}\text { DESS 1998 } \\
\text { LEX-SYLL }\end{array}$ \\
\hline Students & $162 \mathrm{Ss}$ & 42 Ss & 3 Ss & 3 Ss \\
\hline A & Below & $07.9 \%$ & $44.1 \%$ & $100,0 \%$ & $66,7 \%$ \\
\hline \hline & Rise & $29.5 \%$ & $53.4 \%$ & $100,0 \%$ & $100,0 \%$ \\
\hline & Bottom & $37.3 \%$ & $62.7 \%$ & $100,0 \%$ & $100,0 \%$ \\
\hline
\end{tabular}




\begin{tabular}{|c|c|c|c|c|c|}
\hline & Deep & $41.2 \%$ & $69.7 \%$ & $100,0 \%$ & $66,7 \%$ \\
\hline & Low & $37.3 \%$ & $74.4 \%$ & $100,0 \%$ & $100,0 \%$ \\
\hline & Busy & $80.4 \%$ & $79,0 \%$ & $100,0 \%$ & $66,7 \%$ \\
\hline & Grow & $76.5 \%$ & $81.3 \%$ & $100,0 \%$ & $66,7 \%$ \\
\hline & Need & $94.2 \%$ & $95.3 \%$ & $66,7 \%$ & $100,0 \%$ \\
\hline & Between & $88.3 \%$ & $97.6 \%$ & $100,0 \%$ & $100,0 \%$ \\
\hline & Wrong & $98.1 \%$ & $100.0 \%$ & $100,0 \%$ & $66,7 \%$ \\
\hline B & Likely & $09.8 \%$ & $06.9 \%$ & $0,0 \%$ & $33,3 \%$ \\
\hline & Suitable & $09.9 \%$ & $20.9 \%$ & $100,0 \%$ & $66,7 \%$ \\
\hline & Either & $33.4 \%$ & $27.9 \%$ & $100,0 \%$ & $0,0 \%$ \\
\hline & Afford & $13.8 \%$ & $32.5 \%$ & $33,3 \%$ & $33,3 \%$ \\
\hline & Share & $33.4 \%$ & $51.1 \%$ & $100,0 \%$ & $66,7 \%$ \\
\hline & Among & $37.3 \%$ & $65.1 \%$ & $100,0 \%$ & $33,3 \%$ \\
\hline & Wave & $58.9 \%$ & $88.3 \%$ & $100,0 \%$ & $100,0 \%$ \\
\hline & Agree & $96.1 \%$ & $90.6 \%$ & $100,0 \%$ & $100,0 \%$ \\
\hline & Believe & $90.2 \%$ & $93.0 \%$ & $100,0 \%$ & $100,0 \%$ \\
\hline c & Reliable & $13.8 \%$ & $04.6 \%$ & $100,0 \%$ & $0,0 \%$ \\
\hline & Framework & $07.9 \%$ & $06.9 \%$ & $33,3 \%$ & $66,6 \%$ \\
\hline & Cross-section & $04.0 \%$ & $13.9 \%$ & $66.7 \%$ & $66,7 \%$ \\
\hline & Shift & $05.9 \%$ & $23.2 \%$ & $66.7 \%$ & $66,7 \%$ \\
\hline & & & & & \\
\hline
\end{tabular}

As has been already mentioned, groups were formed by means of a purely grammatical test - the MCQ section of the Oxford Placement Test. The LEX-SYLL students were all in the weakest group (see Appendix). One, according to this test, was the weakest student in the intake, being ranked 46 th out of 46 students. The other 2 were respectively ranked 39 th and 31st out of 46 . These students had also been in the weak groups during DEUG. They had had less post baccalaureate language training than the average (50 hours compared to an average of 87 hours). The students in the strongest group consisted 
predominantly of ex Maths Sup/Spé students and IMMERSION students. They had all, except two, had 100 or more hours post baccalaureate training.

These results lend themselves to the following general interpretation:

DESS / DEUG

- The DESS results are better but basically in the same category as the DEUG 1987 results. In both groups a very significant proportion of essential vocabulary was unknown.

- The results for category C words: (Scientific register), were particularly weak for both groups. For the DEUG students, this of course was quite natural as they had not yet undergone any ESP training. The same cannot be said for the DESS students.

- Of the DESS intake at week 4 ,

- $90 \%$ did not know the meaning of framework, likely, reliable

- $70 \%-80 \%$ did not know the meaning of either, shift, suitable

- $50 \%$ did not know the meaning of rise, share, below.

\section{IMMERSION / LEX-SYLL}

- - The results of the IMMERSION group were slightly better, but comparable to the LEX-SYLL group. They had the highest scores (or were ex aequo) for 20 words (out of a possible 23). The LEX-SYLL group obtained the highest score (or ex aequo) 13 out of 23 times.

- - The results for category $\mathrm{C}$ were similar for the two groups. ${ }^{8}$

- - Serious problems occurred with just 4 words: reliable, either, likely, afford

- If one defines as "satisfactory" a group success rate of $66 \%$ and more, then the rate of acceptability is as shown in figure 6.

Figure 6. Rate of acceptibility

\begin{tabular}{|l|l|l|l|l|}
\hline & DEUG & DESS & IMMER & LEX-SYLL \\
\hline \% of sample & $31 \%$ & $44 \%$ & $87 \%$ & $79 \%$ \\
\hline No of words & $(16)$ & $(13)$ & $(3)$ & $(5)$ \\
\hline
\end{tabular}

\section{Test Week 13}

As was said earlier, a further lexis test was part of the exit evaluation. Its contents was restricted to lexical items that had been encountered during the course and which were oriented towards the appropriate scientific register. Figure 7 below,gives the results for a selection of the items tested.

Figure 7. Test - Week 13 (Selection)

\begin{tabular}{|l|l|l|l|l|l|}
\hline & & DESS & IMMERSION & LEX-SYLL \\
\hline & & $41 \mathrm{Ss}$ & $3 \mathrm{Ss}$ & $2 \mathrm{Ss}^{9}$ \\
\hline & likely ${ }^{10}$ & $29.8 \%$ & $0,0 \%$ & $50,0 \%$ \\
\hline & inaccurate & $31.8 \%$ & $66.7 \%$ & $100,0 \%$ \\
\hline
\end{tabular}




\begin{tabular}{|l|l|l|l|l|l|}
\hline settle & $34,0 \%$ & $100,0 \%$ & $50,0 \%$ \\
\hline supply & $43.1 \%$ & $100,0 \%$ & $50,0 \%$ \\
\hline range & $51,0 \%$ & $33.3 \%$ & $50,0 \%$ \\
\hline hence & $54.5 \%$ & $100,0 \%$ & $50,0 \%$ \\
\hline however & $56.8 \%$ & $100,0 \%$ & $100,0 \%$ \\
\hline set & $61.7 \%$ & $100,0 \%$ & $100,0 \%$ \\
\hline rate & $70.2 \%$ & $100,0 \%$ & $100,0 \%$ \\
\hline therefore & $70.4 \%$ & $100,0 \%$ & $100,0 \%$ \\
\hline
\end{tabular}

These results prompt two remarks. On the one hand they more or less reconfirm the results obtained in week 4 - the relative success of the IMMERSION and LEX-SYLL groups stand in sharp contrast to the unsatisfactory results of the DESS group. However, this time there is a new parameter - the 9 weeks' training between the two tests. Bearing this in mind, the results could lend themselves to an even more pessimistic interpretation not only is the DESS proficiency unsatisfactory but, more worrying, it may well be stationary. Notwithstanding the teaching, designed specifically to make core vocabulary prominent, the remedial effect for the DESS group would appear to have been apparently virtually nil or, at least, insufficient to attain any functional proficiency: [5] $_{34} 0 \%$ and more were unable assign a meaning to: likely, inaccurate, settle, however, set, provide, hence, range, supply.

\section{Discussion}

If the results obtained are not atypical then at least two conclusions must be drawn. These conclusions are not intended to be provocative. On the contrary, they are coldly logical conclusions that any course designer or administrator would inevitably be obliged to draw.

\section{Conclusion 1 . The results of at least $40 \%$ of these students are totally unacceptable.}

By totally unacceptable, I mean that the $110^{11}$ or so hours spent on teaching must be considered as a waste of time, a waste of money, and that no obvious rationale for teaching English for Special Purposes can be established. These results are indicative of what one can only call a major professional failure on the part of the University institutions working in this area.

It may be argued, and is perhaps true, that other linguistic skills have been acquired instead. However, taking into account the skills required of DESS students, deprived of basic lexical knowledge, any other competencies are liable to be of secondary importance and mortally flawed.

The results are unacceptable for at least two reasons:

1. At this stage, students should already have had available and have used the English language work tool. Its absence constitutes what may well have been a potential impediment in their 
university studies. This is in fact reflected by complaints from teachers in other fields of study, notably data processing, where training was hindered by the incapacity of certain students to follow software instructions. It should be added that sadly, it would appear that, some of the students at least, have established a modus vivendi with their scanty linguistic skills and appear genuinely convinced that this entitles them to opt out of scientific courses with a stringent English language component.

2. It is also unacceptable because DESS students are at the end of their university training and about to become active in various in-training courses. It is not just touse Swales' terms (1990) that they are "outside their own discourse community". Such a formulation is in fact too charitable -its technicality hides the abyss. These are students who, from a linguistic point of view, are functionally incompetent. suggested by these figures is that the LEX-SYLL students (i.e. students who had basically covered this ground three years before) appeared to show significant improvements in their scores in the exit test as is shown in fig. 8.

Figure 8. Lex-Syll students: Rank order

\begin{tabular}{|l|l|l|l|}
\hline $\begin{array}{l}\text { Student } \\
\text { LEX-SYLL }\end{array}$ & OPT & Lexis & Lexis \\
Week 4 & Week 13 \\
$45 \mathrm{Ss}$ & $47 \mathrm{Ss}$ \\
\hline $3 \mathrm{Hec}$ & 36 & $1=$ & Abs \\
\hline $3 \mathrm{Mar}$ & 40 & 9 & $5=$ \\
\hline $3 \mathrm{Gir}$ & 46 & 41 & $26=$ \\
\hline
\end{tabular}

The progression in rank from week 4 to week 13 could be interpreted as indicating (and for educationalists, it is most surely something that is devoutly to be wished) that what 
has once been learned and partially forgotten can be relearned and reactivated very rapidly.

\section{Teaching vocabulary}

But beyond what has been said, these results pose a more general problem. With intelligent, motivated students, with (on the whole) good material conditions, why is this problem of vocabulary so persistent? The question is not of purely academic interest, for some understanding of this must surely provide clues as to how the problem might be overcome.

It is important, however, first of all, to point out once again, that teaching ESP at the University cannot replicate immersion. With a timetable of no more than 50 hours or so at DEUG level it is illusory to think that ESP can ever be a painless osmosis. Fifty hours teaching are not sufficient to allow natural assimilation and mastery via a course of intensive, motivating, reading and listening activities, as a Krashen-like model would require. There is not enough contact for immersion strategies to function. To put this in perspective, Coady (1997: 225) for example, reports that, for a word to be assimilated, it needs to be encountered 12 times. To give an idea of what this means in practice the following frequencies were found using a New Scientist biology corpus totalling 32,000 words (see fig. 9).

Figure 9. New Scientist biology corpus

\begin{tabular}{|c|c|c|c|}
\hline however & 18 & average & 6 \\
\hline range & 12 & suitable & 4 \\
\hline aim & 8 & accurate & 4 \\
\hline set & 6 & likely & 4 \\
\hline scale & 6 & & \\
\hline
\end{tabular}

37 For any significant number of words to be learnt by assimilation from reading a massive, and in terms of a non-specialist student population, disproportionate investment in reading would be required. All the more so, because, as Altmann (1997: 93) remarks, the assimilation of lexis depends not only on frequency but on prominence. It is only once an item has entered conscious attention that it is likely to be noticed again. This rider is not without importance as the chief characteristic of an unknown word is that it is, by definition, devoid of information value. Consequently, its prominence may be minimal. This could explain the findings of Kelly (1990) who reports that, confronted with an unknown word, most learners' reaction is not, as we might fondly imagine, to engage in some complex cognitive elucidation process, but simply to skip it.

If naturalistic assimilation is not a viable solution then, like the venerable Hobson, we are left with a choice of one. Quite simply, the lexis has to be taught and to be learnt. Basically, there are 3 requirements for this. Two of them - defining the contents of the syllabus and suggesting management strategies and learning tools - are essentially the 
teacher's responsibility. However, in so far as the brunt of the work is concerned, the learning, the student alone has to shoulder this responsibility. Am I wrong in suggesting that, alas, in the present educational ethos that it is all too frequent that not one of these three ingredients is satisfied? Many of us would agree with Arnaud and Savignon when they say,

very little specific vocabulary teaching is done in France. (1997: 168)

If this is so, why is it so? Where does the resistance come from?

\section{Obstacles to teaching vocabulary} charms of the natural, has succumbed to the sirens of creativity and the expression of self. For it is I think true to say, that to suggest today that making the conscious, artificial learning of vocabulary, within a teacher-defined schedule a central aim of a programme is widely considered to be reactionary, stultifying and wrong for at least 3 reasons.

\section{Stevick's objection}

44 It is claimed that learning which is not nourished by interest and motivation is pedagogically ill-founded. Defenders of the argument joyfully quote Stevick (1982):

if you want to forget something, put it on a list.

45 An amusing, pithy paradox with enough truth in it to stick and make us laugh. But laughter does not always sharpen logic. In fact, is not truth being slyly subverted? What we are reacting to in Stevick's remark is the recognition of that immense cerebral energy 
that is generated when there is total identification between action, discovery and desire. This occurs in the language play of infants, in the enthusiasms and passions of grown women and men. It should happen occasionally in the classroom, but can only do so rarely; it is seldom indeed that the classroom can be the most vibrant, meaningful, existential experience, that it can become a vicarious embodiment of "Life Itself".The classroom is not made for that sort of thing. It is an unnatural place designed to do an unnatural thing, namely, to dramatically accelerate the learning process. One must remember that a 50 hour DEUG course corresponds in hours to no more than a six day stay in immersion. ${ }^{12}$ As language teachers, we are paid to have a higher productivity than that.

To return to Stevick, have we not let ourselves be tricked by over-hastily assigning the causality in his aphorism? It is not the list that causes the cerebrum to shift into neutral, contrariwise, this is the consequence of the low priority. Surely, what we are assenting to with Stevick is the recognition that,

The moment you are tempted to put something on a list it is a sure sign that there are other things that interest you more.

After all, we, and so one must suppose does Stevick, very consciously use lists, depend on them even, for otherwise our respective larders, fridges and weekly appointments would be in a sorry state indeed.

To Stevick's aphorism, I find more helpful and would oppose a remark by Jean Bornarel, Professor of Physics and Director of Les Presses Universitaires de Grenoble, (he commissioned Minimum Competence in Scientific English) who observed,

We (scientists) are fast learners, but the trouble is we are short of time. What we need from you (English teachers) is to know what we've got to learn.

\section{The "moreover" syndrome}

A second objection is that many consider that focusing on a core vocabulary is dangerous and can be reductionist because the imperfect mastery that it leads to somehow betrays the rich texture language. The exasperation of Rézeau (1999) echoes what we have all thought and said when confronted by the seemingly endless barrage of ill-used and stereotyped:

moreovers, on the other hands, in a nutshells (sic).

And doubtless, at times, as aghast we contemplate how our very own students produce the opposite of what we were aiming for, language that seems to be insensitive, unlettered, and little more than a parrot-like repetition, we may be inclined to cover our heads with ashes or over-hastily castigate "core language" as an easy scapegoat accountable for this atomistic, truncated caricature of language so totally blind to context, to Gestalt, to collocation, and textual cohesion. But, this opposition between atomistic and Gestalt is, I would plead, only an artefact of the situation. A core lexis is in no way in opposition to higher levels of organisation. The "moreover" syndrome is not a result "per se" of focusing on core lexis. This ungainly, wooden parlance is perhaps just one of the necessary stations through which it is the lot of all learners to pass: a stepping stone, an interlanguage, no more, no less. 


\section{Objection No. 3}

51 Finally, perhaps partly because of what has just been said, but also due to deeper considerations concerning the history of Academia, to questions of status, of power and prestige, the teaching of vocabulary is too often regarded with blatant disdain; it is not considered to be the job of University teaching. Witness the withering condescension when I first presented Minimum Competence in Scientific English:

Yes, but so reductionist.

The lexis, in so far as it deals with the part of language that is "not rule-governed" is considered to be of minor interest. As Zimmerman, quoting Richards says (1997):

lexis has never been a serious candidate for theorising.

And assuredly, if one looks at the centres of interest that have been at the hub of linguistics and didactics since the demise of structuralism one finds a series of heavyweight theoretical approaches, a series of clashes between competing models, each with its own panache and brilliance. Remember those halcyon days, the epic confrontation, when Chomsky (1959) brought Skinner to his knees and the remains of behaviourism were consigned to an ossuary, when Hymes (1971) parried and counterthrust to enrich the definition of language with "communicative competence".There were Functional and Notional syllabuses. Halliday (1978) proposed Systemics and "Language associal semiotic". There was the Council of Europe, there was schemata theory, discourse analysis and neural networks. All innovative, refreshing and intellectually exciting approaches and with, in many cases (but not all ${ }^{13}$ ) considerable practical teaching implications. Paradigm jousted with paradigm. This was where the "scene" was, the primrose path of the "chercheur". But, and we forget it at our peril, our professional role is schizoid. "Chercheurs» we may be, but we are "enseignants" too. Perhaps, in the exhilaration of the action we have forgotten our alter egos, our lesser selves. Happy to be in the white-collared jobs, have we not been tempted to commit that heinous crime of passing the baby, of relegating the problem of vocabulary to someone else - to the mechanics perhaps?

And so the end result is a debilitating vicious circle of failure, adapted from Nuttal, 1982 (see fig. 10).

Figure 10. Vicious circle of failure

\begin{tabular}{|ll|}
\hline impoverished lexis $\rightarrow$ & $\begin{array}{l}\text { meaning is veiled } \rightarrow \\
\text { reading is burdensome } \rightarrow\end{array}$ \\
no learning $\rightarrow$ & dislike of reading - little reading \\
\hline
\end{tabular}

Adapted from Nuttal, 1982

\section{Conclusion}

If the description that I have given approaches reality and if the situation cannot be improved than, as I said at the outset, I fail to see any valid reason why the generalised teaching of English in Scientific Institutions should be prolonged. However, the results of those students who did follow a lexical syllabus suggest that this lexical impoverishment 
is not inexorably preordained. The sample is tiny but seems to suggest quite consistently that intensive, suitably oriented courses can enable even weak students to obtain an honourable mastery of the lexicon in the required register (Fig. 8).

The implication of this is that if there is to be a general improvement of lexical proficiency the problem has to be approached structurally. The minimum requirements should include at least the following:

1. It is essential to have at the level of second year DEUG an ESP course which is long enough in hours and in duration for the required linguistic programme to be assimilated. ${ }^{14}$ The main linguistic component of the course should be a lexical programme combined with a reading programme, constructed around a core lexis of some 5,000 words.

2. The lexical programme must, in so far as the students are concerned, be "incontournable". This means that it must be rigorously tested during the year and be a heavily loaded part of the final evaluation mark. As we all know, it is (sadly) the evaluation system which defines the efficiency of both the teaching and the learning.

3. Thirdly and finally, (and of course, this is much more difficult to implement) 2nd and 3rd cycles should consistently stipulate a certain lexical/linguistic prerequisite for any student entering a post-DEUG course. Students who have not attained a defined level should be required to do remedial work to qualify (on their own, or supervised) in the Language centre before being admitted. This clause is important as it lays the responsibility where it should be: on the upstream institutions on the one hand and on the learners on the other.

57 I would like to make one finally cautionary remark. This nagging drone, this repeated insistence on low level lexical proficiency does not mean in any way that I wish to suggest that this is all that there is to teaching languages. What I am simply saying is that it is a prerequisite, quite literally it is a sine qua non whose absence makes any discussion of meaningful objectives in ESP vacuous.

In an earlier issue of ASp, Jean Sabiron (1996) wrote of our responsibilities as ESP teachers to young university students. He talked in terms of,

une vraie progression intellectuelle et humaine... une culture procédurale... de l'étape métacognitive d'un savoir-être... d'une méthodologie critique universitaire...

I totally adhere to this pedagogical "high ground". All the more so as Sabiron insists that this scientific culture, to be developed in the 2nd and 3rd cycles, depends on the prior mastery of the nuts and the bolts, the lexis and the functions of scientific discourse.

\section{BIBLIOGRAPHY}

Alderson, J.C. 1984. "Reading in a foreign language: a reading problem or a language problem?". In Alderson \& Urquhart (eds.), Reading in a foreign language. London: Longman.

Altman, R. 1997. "Oral production of vocabulary: A case study". In Coady J. \& T. Huckin (eds.), Second Language Vocabulary Acquisition. Cambridge: Cambridge University Press. 
Arnaud, P.J.L. \& S.J. Savignon. 1997. "Rare words, complex lexical units and the advanced learner”. In Coady J. \& T. Huckin (eds.), Second Language Vocabulary Acquisition. Cambridge: Cambridge University Press.

Carter, R. 1987. Vocabulary: Applied Linguistic Perspectives. London: Allen \& Unwin.

Chomsky, A.N. 1959. “A review of B.F. Skinner's 'Verbal behaviour'”. Language 35/1, 26-58.

Chomsky, A.N. 1966. "Linguistic Theory". In Report of N.E. Conference on the teaching of foreign languages. Mensha, WI.

Coady, J. “L2 Vocabulary acquisition through extensive reading”. In Coady J. \& T. Huckin (eds.), Second Language Vocabulary Acquisition. Cambridge: Cambridge University Press.

Coady, J. \& T. Huckin (eds.). 1997. Secondary Language Vocabulary Acquisition. Cambridge: Cambridge University Press, 1997.

Coste, D. 1994. Linguistique de l'acquisition des langues étrangères. Paris: Didier.

Galisson, R. 1991. De la langue à la culture par les mots. Paris: CLÉ International.

Grabe, W. \& F.L. Stoller. 1997. "Reading and vocabulary development in second language: A case study". In Coady J. \& T. Huckin (eds.), Second Language Vocabulary Acquisition. Cambridge: Cambridge University Press.

Halliday, M.A.K. 1978. Language as Social Semiotic: The social interpretation of language and meaning. London: Edward Arnold.

Hindmarsh, R. 1980. The Cambridge English Lexicon. Cambridge: Cambridge University Press.

Hymes, D. 1971. On Communicative Competence. Philadelphia, PA: Pennsylvania University Press.

Kelly, P. 1990. “Guessing: No substitute for systematic learning of lexis”. System 18/2, 199-207.

Laufer, B. 1997. “The lexical plight in second language reading: Words you don't know, words you think you know, and words you can't guess". In Coady J. \& T. Huckin (eds.), Second Language Vocabulary Acquisition. Cambridge: Cambridge University Press.

Nation, P. \& J. Newton. 1997. “Teaching Vocabulary”. In Coady J. \& T. Huckin (eds.), Second Language Vocabulary Acquisition. Cambridge: Cambridge University Press.

Nattinger, J.R. \& J.S. De Carrico. 1997. Lexical Phrases and Language Teaching. Oxford: Oxford University Press.

Nurweni, A. and J. Read. 1999. “The English vocabulary knowledge of Indonesian University Students". English for Specific Purposes 18/2, 161-175.

Nuttal, C. 1982. Teaching Reading Skills in a Foreign Language. London: Heinemann.

Pugh, A.K. \& J.M. Ulijn (eds.). 1984. Reading for Professional Purposes: Studies and practices in native and foreign languages. London: Heinemann.

Rézeau, J. 1999. “Learner English on computer”. System 27/2, 277-288.

Sabiron, J. 1996. “Cohérences plurielles”. ASp 11-14, 239-252.

Singleton, D. 1999. Exploring the Second Language Mental Lexicon. Cambridge: Cambridge University Press.

Stevick, E. 1982. Teaching and Learning Languages. Cambridge: Cambridge University Press. Swales, J.M. 1990. Genre Analysis: English in Academic and Research Settings. Cambridge: Cambridge University Press. 
Ulijn, J.M. \& F. Salager-Meyer. 1998. "The professional reader and the text: insights from L2 research". Journal of Research in Reading 21/2, 79-85.

Upjohn, J. 1991. "Minimum Competence in Scientific English: Rationale and description". Actes du XII Colloque du GERAS. Bordeaux: Université Bordeaux 2, 245-254.

Upjohn, J., Blattes, S. \& V. Jans. 1991. Minimum Competence in Scientific English. Grenoble: Presses Universitaires de Grenoble.

Yang, L. 1997. “Tracking the acquisition of L2 vocabulary: The Keki language experiment”. In Coady J. \& T. Huckin (eds.), Second Language Vocabulary Acquisition. Cambridge: Cambridge University Press.

Zimmerman, C.B. 1997. "Historical Trends in second language vocabulary Instruction". In Coady J. \& T. Huckin (eds.), Second Language Vocabulary Acquisition. Cambridge: Cambridge University Press.

\section{APPENDIXES}



\section{NOTES}

1. At this stage, a precise definition of autonomous reading is not necessary. Broadly speaking, it can be defined as the ability to read and exploit texts within one's own field with no more than occasional recourse to a dictionary.

2. Examples of "academic vocabulary" given by Nation and Newton include: abandon, alternative, comply, denote, element, evident. 
3. The figures for the low-frequency words with their meagre coverage potential are perhaps the most eloquent advocates for the importance of core vocabulary.

4. The number of students varies in the different tables because of absences, etc.

5. N.B. Only the MCQ was used for the placement test. The overall proficiency was rated using two parts of the Oxford Placement Test: MCQ + Oral discrimination.

6. Since 1987, there has been a noteworthy linguistic shift and manage, monitor, hardware have been surreptitiously hi-jacked into French technical jargon (accompanied doubtless, by much gnashing of teeth on the part of the Académie Française). Other words, e.g., alloy, proved to be too little known to act as efficient probes, while words like reading have multiple meanings outside the technical register and thus provide polluted data.

7. We hold no illusions as to the statistical value of such samples. However, some confidence can be had in their illustrative value. Predictably, the Immersion students had the best results and, for several years, we have had independent corroboration through reports of the satisfactory performance of ex LEX-SYLL students entering local engineering schools (I.S.T.G.) (E. Anne, M. Greene, C. West).

8. With the exception of "reliable", perhaps a casualty of the meagre sample.

9. Only two students because one had left the course.

10. This notoriously bothersome word was used in both tests.

11. i.e. 87 hrs pre DESS +24 hrs DESS.

12. Similarly, Singleton (1998: 52) has calculated that a year's naturalistic exposure corresponds to 18 years' classroom exposure.

13. Chomsky (1966), unheeded, always insisted that TG (Transformational Grammar) was of no relevance to the teaching of language.

14. A minimum of 50 hours over a period of one year is necessary.

\section{ABSTRACTS}

A mastery of a core lexis is an essential component of reading proficiency. A study was carried out of lexical proficiency of four different groups of students. While it was found that students who had experienced immersion or who had followed a lexical syllabus had satisfactory results, a high proportion of DESS students, despite an average of 87 hours university language training, had levels that were so low as to prevent the use of English as a working tool. Reasons for the neglect of the lexis are discussed. It is concluded that unless results can be improved it is difficult to find a rationale for teaching English to students of science.

Une des composantes primordiales de la lecture est la maîtrise d'un lexique de base. Une étude sur la compréhension lexicale a été menée avec 4 groupes différents d'étudiants. Les résultats montrent que les étudiants ayant séjourné en pays anglophones ou ayant suivi un programme linguistique à orientation lexicale ont un niveau satisfaisant, alors que celui d'une proportion élevée d'étudiants de DESS, malgré 87 heures en moyenne de formation linguistique à l'Université, les met dans l'incapacité de se servir de l'anglais comme outil de travail. Les raisons qui pourraient expliquer ces lacunes sont passées en revue. Sauf amélioration, ces résultats semblent mettre en cause l'enseignement de l'anglais à des filières scientifiques. 
INDEX

Mots-clés: anglais scientifique, compétence minimum, langue de spécialité, lecture, lexique de base, niveau de sortie, programme lexical

Keywords: competence (minimum), core lexis, ESP, exit proficiency, lexical syllabus, reading, scientific English

\section{AUTHOR}

\section{JONATHAN UPJOHN}

Jonathan Upjohn est le co-auteur de Minimum Competence in Scientific English 1991, Listening Comprehension in Scientific English 1994, Speaking Skills in Scientific English 1997 (Presses universitaires de Grenoble). Responsable de 1987 à 1998, de l'enseignement de langues en Deug A à Grenoble 1 , il démissionne à la suite de la réduction de $50 \%$ du budget des langues. Il est actuellement responsable de l'enseignement de l'anglais en Aménagement du territoire/DESS Physique. Jonathan.Upjohn@ujf-grenoble.fr 